IDENTIFIKASI KEBERADAAN SEROVAR BAKTERI LEPTOSPIRA PADA SERUM DARAH SUSPEK LEPTOSPIROSIS DI KECAMATAN MANGGALA KOTA MAKASSAR

\title{
Identification of Leptospira Serovar in Leptospirosis Suspect Serum in Manggala District, Makassar City
}

\section{Sri Indi Rahmadanti Haryono ${ }^{1 *}$, Syamsuar Manyullei $^{2}$, Hasnawati Amqam}

${ }^{1}$ Departemen Kesehatan Lingkungan, FKM Universitas Hasanuddin, sriindirahmadanti@gmail.com

${ }^{2}$ Departemen Kesehatan Lingkungan, FKM Universitas Hasanuddin, manongkoki@yahoo.com

${ }^{3}$ Departemen Kesehatan Lingkungan, FKM Universitas Hasanuddin, nana_azzahra@yahoo.com

*Alamat Korespondensi: Departemen Kesehatan Lingkungan Fakultas Kesehatan Masyarakat Universitas Hasanuddin, Jl. Perintis Kemerdekaan KM 10, Tamalanrea Kota Makassar Sulawesi Selatan

\section{ARTICLE INFO \\ Article History: \\ Received February, $24^{\text {th }}, 2020$ \\ Revised form March, $8^{\text {th }}, 2020$ \\ Accepted June, $17^{\text {th }}, 2020$ \\ Published June, 2020}

\section{Kata Kunci:}

Leptospirosis;

leptospira;

microscopic aglutination test;

Keywords:

Leptospirosis;

leptospira;

microscopic aglutination test;

\begin{abstract}
ABSTRAK
Latar belakang: Leptospirosis atau juga biasa disebut Weil disease adalah penyakit infeksi akut yang dapat menyerang manusia dan hewan serta digolongkan sebagai penyakit zoonosis. Leptospirosis disebabkan oleh bakteri dari genus Leptospira yang terdapat pada hewan pengerat. Tujuan : penelitian ini bertujuan untuk mengetahui keberadaan serovar bakteri Leptospira pada serum darah suspek leptospirosis menggunakan metode Microscopic Aglutination Test (MAT). Metode: Jenis penelitian ini yaitu observasional deskriptif menggunakan teknik accidental sampling dengan total 31 sampel. Pengambilan sampel dilakukan di Puskemsmas Antang, Puskesmas Batua dan Puskesmas Bangkala di Kecamatan Manggala selama dua minggu. Analisis data pada penelitian ini yaitu deskriptif yang dimana hasil dipaparkan melalui tabel dan narasi. Hasil: Pemeriksaan MAT pada serum darah menghasilkan sebelas sampel positif Leptospira (37\%) dengan serovar Hebdomadis, Djasiman, Mini, Icterohaemorrhagiae, Bangkingan dan Bataviae. Kesimpulan: Keberadaan bakteri Leptospira pada serum darah individu suspek dengan menggunakan Metode MAT didapatkan sebanyak 11 sampel serum darah positif. Perlu mengadakan dan meningkatkan kegiatan penyuluhan khusus tentang leptospirosis dan penegakan diagnosis pada masyarakat atau pekerja yang mengalami gejala atau suspek leptospirosis.
\end{abstract}

\section{ABSTRACT}

Background: Leptospirosis or also commonly called Weil disease is an acute infectious disease that can attack humans and animals and is classified as a zoonotic disease. Leptospirosis is caused by bacteria of the genus Leptospira found in rodents. Purpose: This study aims to determine the presence of Leptospira bacteria serovar in blood serum suspected of leptospirosis using the Microscopic Aglutination Test (MAT) method. Methods: This type of 
research is descriptive observational using accidental sampling technique with a total of 31 samples. Sampling was conducted at the Antang Community Health Center, Batua Health Center and Bangkala Health Center in Manggala District for two weeks. Data analysis in this research is descriptive in which the results are presented through tables and narratives. Results: The results of MAT examination on blood serum yielded eleven positive samples of Leptospira (37\%) with serovar Hebdomadis, Djasiman, Mini, Icterohaemorrhagiae, Bangkingan and Bataviae. Conclusion: The presence of Leptospira bacteria in the blood serum of suspected individuals using the MAT Method obtained 11 samples of positive blood serum. Need to conduct and improve special counseling activities about leptospirosis and diagnosis enforcement in the community or workers who experience symptoms or suspected leptospirosis.

(C)2020 by author.

Published by Faculty of Public Health, Hasanuddin University. This is an open access article under CC-BY-SA license (https://creativecommons.org/licenses/by-sa/4.0/)

\section{PENDAHULUAN}

Leptospirosis atau juga biasa disebut Weil disease adalah penyakit infeksi akut yang dapat menyerang manusia dan hewan serta digolongkan sebagai penyakit zoonosis. ${ }^{1}$ Leptospirosis disebabkan oleh bakteri dari genus Leptospira yang terdapat pada hewan pengerat. Beberapa jenis hewan yang dapat menjadi sumber penyakit leptospirosis diantaranya yaitu tikus atau rodent, babi, sapi, kambing, domba, kuda, anjing, kucing, serangga, burung dan insektivora. Namun, tikus merupakan hewan yang paling sering menjadi sumber penyakit leptospirosis karena tikus bertindak sebagai inang alami bakteri Leptospira dan memiliki daya reproduksi yang tinggi. ${ }^{2}$ Bakteri Leptospira memiliki tingkat prevalensi yang cukup tinggi dengan distribusi bakteri tersebut di seluruh dunia. ${ }^{3}$

Persebaran leptospirosis berada di seluruh dunia dengan wilayah endemik yaitu negara-negara yang beriklim subtropis atau tropis. ${ }^{2}$ Insiden leptospirosis di negara beriklim tropis (hangat) pada umunya terjadi sebanyak 10-100 per 100.000 penduduk setiap tahunnya, sedangkan di negara beriklim sedang insiden leptospirosis lebih sedikit terjadi yaitu 0,1 - 1 per 100.000 penduduk setiap tahunnya. ${ }^{4}$ International Leptospirosis Society menyatakan bahwa Asia Selatan dan Tenggara, Pasifik Barat, Amerika Tengah dan Selatan serta Afrika memiliki perkiraan beban penyakit leptospirosis tertinggi. Hal ini dapat dibuktikan berdasarkan kasus leptospirosis di Eropa dilaporkan sebanyak 1.593 kasus pada tahun 2014, termasuk 937 yang telah dikonfirmasi dengan tingkat pemberitahuan yaitu 0,23 kasus per 100.000 penduduk. $^{5}$ Amerika latin telah melaporkan kasus leptospirosis pada tahun 2014 yaitu sebanyak 10.702 kasus dengan persentasi sebesar $95 \% .^{6}$ 
Menurut Yunianto, dkk (2012) menyatakan bahwa Indonesia sebagai negara dengan kasus leptospirosis cukup tinggi dan berada pada peringkat ketiga di dunia. Kasus leptospirosis di Indonesia pada tahun 2010 terjadi di tujuh provinsi yaitu Provinsi DKI Jakarta, Jawa Barat, Jawa Tengah, DI Yogyakarta, Bengkulu, Kepulauan Riau dan Sulawesi Selatan. Leptospirosis di Indonesia dari Tahun 2004-2011 cenderung meningkat, tahun 2011 terjadi 690 kasus Leptospirosis dengan 62 orang meninggal (CFR 9\%). Peningkatan ini terjadi dikarenakan KLB di Provinsi Yogyakarta (Kabupaten Bantul dan Kulon Progo), dimana kejadian leptospirosis yaitu 539 kasus dengan 40 kematian (CFR 7,42\%) dan Provinsi Jawa Tengah dengan 143 kasus dengan 20 kematian (CFR 10,6\%). ${ }^{7}$

Peningkatan kasus leptospirosis terjadi lagi pada tahun 2018 setelah di tahun 2016 hanya mencapai 830 kasus, kini di tahun 2018 menjadi 894 kasus. Angka kematian akibat leptospirosis di Indonesia tahun 2014-2018 berturut-turut adalah 61 jiwa, 65 jiwa, 62 jiwa, 108 jiwa, 148 jiwa dengan angka CFR 11,75\%, 17,76\%, 7,44\%, 16,88\% dan 16,55\% sehingga dapat disimpulkan kasus kematian akibat leptospirosis relatif meningkat dan kematian tertinggi terjadi pada tahun $2018 .{ }^{8}$ Peningkatan jumlah penderita leptospirosis dapat terjadi selama musim hujan dan bahkan dapat mencapai proporsi epidemi jika terjadi banjir dengan pola cuaca yang ekstrim. ${ }^{1}$ Air banjir akan menyebabkan Leptospira tersebar lebih luas, sehingga manusia dapat terinfeksi bakteri Leptospira melalui kontak dengan air/banjir, tanah (lumpur), tanaman yang tercemar oleh air seni hewan yang terinfeksi bakteri Leptospira. $^{2}$

Kota Makassar diketahui merupakan ibu kota provinsi Sulawesi Selatan yang memiliki beberapa daerah rawan banjir. Salah satu wilayah di Kota Makassar yang merupakan daerah rawan banjir yaitu Kecamatan Manggala. Laporan tahunan Dinas Kesehatan Kota Makassar tahun 2018 menyebutkan bahwa Kecamatan Manggala merupakan salah satu kecamatan yang rawan terhadap bencana banjir. Sulitnya proses diagnosis menyebabkan kasus lepstospirosis kurang dilaporkan dan merupakan salah satu penyakit infeksi yang terabaikan (neglected infectious diseases). Penemuan penderita seringkali tidak optimal karena terjadi under diagnosis atau misdiagnosis. Hal tersebut sangat berakibat dalam keterlambatan tatalaksana penderita yang dapat memperburuk prognosis meskipun sebenarnya penyakit ini pada umumnya mempunyai prognosis yang baik. ${ }^{10}$ Oleh karena itu, pentingnya mengidentifikasi individu yang memiliki gejala leptospirosis untuk mencegah dan menghindari kesalahan diagnosis.

\section{METODE}

Jenis penelitian ini adalah observasional deskriptif yang dilaksanakan di Puskesmas Antang, Puskesmas Batua dan Puskesmas Bangkala Kecamatan Manggala Kota Makassar pada tanggal 2-19 Januari 2020 dan dilakukan pemeriksaan di Balai Besar Reservoar dan Vektor B2P2VRP Salatiga. Pemeriksaan dilakukan pada hari rabu dan kamis tanggal 21-22 Februari 2020. Populasi pada 
penelitian ini adalah seluruh pasien yang berkunjung di Puskesmas Antang, Puskesmas Batua dan Puskesmas Bangkala, sementara sampel pada penelitian ini adalah pasien yang memiliki kriteria suspek leptospirosis meliputi demam lebih dari 3 hari, sakit kepala dan nyeri otot. Teknik pengambilan sampel menggunakan non probability sampling yaitu accidental sampling. Data yang diperoleh dari data primer yaitu gejala leptospirosis dan hasil pemeriksaan MAT. Data yang diperoleh kemudian diolah menggunakan SPSS kemudian disajikan dalam bentuk tabel dan narasi.

Alat dan bahan yang digunakan pada penelitian ini yaitu spoit alat yang digunakan untuk mengambil sampel darah, Centrifuge alat yang digunakan untuk memisahkan antara darah segar dan serum darah, Mikrotube digunakan sebagai wadah serum, coolbox, parfilm digunakan untuk pengepakan sampel. Pada pemeriksaan MAT, tahap pengenceran dan penambahan kultur dilakukan dengan penambahan larutan pengencer dan serovar bakteri Leptospira, dilakukan tahap inkubasi selama 2 - 4 jam dengan suhu $37^{\circ} \mathrm{C}$, dan dilakukan tahap pembacaan bakteri menggunakan mikroskop medan gelap.

\section{HASIL}

Subyek pada penelitian ini adalah suspek leptospirosis, sampel tersebut diambil secara accidental yang berarti pasien yang memenuhi kriteria suspek dan bersedia untuk diambil darahnya dan berapa pun jumlahnya akan dijadikan sebagai sampel (Tabel 1).

Tabel 1

Hasil Pemeriksaan Microscopic Aglutination Test (MAT) pada Sampel Serum Darah Suspek Leptospirosis

\begin{tabular}{cccc}
\hline No & Kode Sampel & Hasil Pemeriksaan & Ket \\
\hline 1 & 1 & Negatif & - \\
2 & 2 & Negatif & - \\
3 & 3 & Negatif & - \\
4 & 4 & Negatif & - \\
5 & 5 & Negatif & - \\
6 & 6 & Negatif & - \\
7 & 7 & Negatif & - \\
8 & 8 & Negatif & - \\
9 & 9 & Positif & Icterohaemorrhagiae \\
& & & Bataviae \\
& & & Djasiman \\
10 & 10 & Positif & Bataviae \\
& & & Mini \\
11 & 11 & Negatif & - \\
12 & 12 & Negatif & - \\
13 & 13 & Negatif & - \\
14 & 14 & Negatif & - \\
15 & 15 & Negatif & - \\
16 & 16 & Negatif & - \\
17 & 17 & Negatif & - \\
18 & 18 & Positif & Bataviae \\
19 & 19 & Positif & Bataviae \\
\hline
\end{tabular}




\begin{tabular}{cccc}
\hline 20 & 20 & Negatif & - \\
21 & 21 & Positif & Bataviae \\
22 & 22 & Negatif & - \\
23 & 23 & Positif & Icterohaemorrhagiae \\
& & & Djasiman \\
24 & 24 & Positif & Bataviae \\
25 & 25 & Positif & Bataviae \\
26 & 26 & Negatif & - \\
27 & 27 & Negatif & - \\
28 & 28 & Negatif & - \\
29 & 29 & Positif & Hebdomadis \\
30 & 30 & Positif & Hebdomadis \\
31 & 31 & Positif & Bangkinan \\
\hline Sumber: Data Primer, 2020 & &
\end{tabular}

Hasil pengambilan sampel darah yang dilakukan di tiga puskesmas yaitu Puskesmas Antang, Puskesmas Batua, dan Puskesmas Bangkala sebanyak 31 sampel. Hasil pemeriksaan MAT menunjukkan dari 31 sampel yang diambil darahnya, terdapat 11 sampel yang postif Leptospira dengan kode sampel yang positif yaitu kode sampel nomor 9, 10, 18, 19, 21, 23, 24, 25, 29, 30 dan 31. Sampel yang postif Leptospira adalah pasien dari Puskesmas Antang.

\section{PEMBAHASAN}

Pengambilan sampel darah dilakukan di Puskesmas Antang, Puskesmas Bangkala dan Puskesmas Batua. Total sampel yang didapatkan selama proses yaitu sebanyak 31 sampel yang memenuhi kriteria suspek. Gejala leptospirosis mirip dengan penyakit infeksi lainnya seperti influenza, meningitis, hepatitis, demam dengue, demam berdarah dengue dan demam virus lainnya. Gejalaklinis leptospirosis terbagi ke dalam 3 fase yang meliputi fase leptospiremia, fase imun, dan fase penyembuhan. Pada fase leptospiremia, penderita akan mengalami Demam mendadak tinggi sampai menggigil disertai sakit kepala, nyeri otot, hiperaestesia pada kulit, mual muntah, diare, bradikardi relatif, ikterus, injeksi silier mata. Fase ini berlangsung 4-9 hari dan berakhir dengan menghilangnya gejala klinis untuk sementar. ${ }^{11}$

Berdasarkan Gejala leptospirosis yang umumnya dirasakan responden, persentasi tertinggi yaitu demam lebih dari 3 hari dan nyeri kepala sebanyak 96,8\%. Selain itu, nyeri otot juga memiliki persentasi sebesar $80,6 \%$. Gejala yang paling jarang dirasakan responden yaitu konjungtivitis atau peradangan selaput yang meliputi bagian depan mata dan menyebabkan mata berwarna kemerahan sebesar $1 \%$. Sedangkan, untuk gejala albuminuria, ikterik dan perdarahan belum didapatkan di responden pada penelitian kali ini yaitu sebesar $0 \%$.

Penderita penyakit leptospirosis, terlebih dahulu akan menunjukkan gejala leptospirosis yang berada pada fase pertama gejala klinis yaitu Fase leptospiremia, dimana pada fase ini bakteri Leptospira telah berada di dalam darah dan cairan serebrospinal, sehingga menimbulkan gejala demam tinggi, menggigil yang mendadak dan disertai sakit kepala, rasa sakit dan nyeri pada otot 
terutama paha, betis dan pinggang yang disertai nyeri tekan. ${ }^{10}$

Kuman Leptospira akan masuk dalam peredaran darah yang ditandai dengan adanya demam dan berkembang pada target organ serta akan menunjukkan gejala infeksi pada organ tersebut. Masa inkubasi dari leptospirosis 4-19 hari, rata-rata 10 hari. Penularan langsung dari manusia ke manusia jarang terjadi. ${ }^{11}$ Penelitian mengenai identifikasi leptospirosis serovar di daerah rawan banjir di Kabupaten Wajo Sulawesi Selatan yang menunjukkan bahwa daerah rawan banjir berpotensi menimbulkan penyakit leptospirosis. Hasil ini dibuktikan dengan ditemukannya beberapa jenis serovar pada serum di Wajo yang merupakan daerah rawan banjir yaitu serovar Bangkinang (Ban), Grihalotyphosa (Gri), Canicola (Can), Robinsoni (Rob), Bataviae (Bat), Mini (Min) dari spesies serovar yang ditemukan pada anjing, tikus dan sapi. ${ }^{18}$

Infeksi pada umumnya sering terjadi melalui selaput lendir mata, mulut, hidung atau saluran genital. Masa bacteremia yang dapat berlangsung selama seminggu, dimulai satu atau dua hari setelah infeksi. Selama periode ini, leptospira dapat diisolasi dari darah dan sebagian besar organ tubuh dan juga dari cairan serebrospinal. Fase bakteremia primer berakhir dengan munculnya antibodi yang bersirkulasi dan dapat terdeteksi biasanya setelah 10-14 hari. Periode bakteremia sekunder muncul setelah periode bacteremia primer yaitu 15-26 hari dan pada umumnya jarang dilaporkan. ${ }^{12}$

Setelah infeksi, leptospira muncul dalam darah dan menyerang hampir semua jaringan serta organ. Bakteri ini kemudian dibersihkan dari tubuh oleh respon imun inang untuk infeksi. Leptospira dapat menetap di tubulus ginjal dan dalam urin selama beberapa minggu hingga beberapa bulan dan kadang-kadang bahkan lebih lama. Setelah itu, bakteri Leptospira dibersihkan dari ginjal dan organ lain tetapi dapat bertahan di mata lebih lama. ${ }^{2}$

Faktor yang bisa memengaruhi kejadian leptospirosis di antaranya adalah faktor umur, jenis kelamin, jenis pekerjaan, riwayat luka, dan personal hygiene. ${ }^{13,14}$ Berdasarkan jenis pekerjaan, leptospirosis umumnya menyerang para petani, pekerja perkebunan, pekerja tambang, pembersih selokan, pekerja rumah potong hewan dan militer. ${ }^{10}$ Penelitian yang dilakukan oleh Dewi \& Yudhastuti (2019) tentang faktor risiko kejadian leptospirosis di wilayah Kabupaten Gresik menunjukkan bahwa sebagian besar responden yang menderita leptospirosis adalah mereka yang kontak dengan air yaitu petani, pengupas kerang dan pekerja tambak. ${ }^{15}$

Sejak 1936 dilaporkan di Indonesia telah diisolasi berbagai serovar Leptospira, baik dari hewan liar maupun hewan peliharaan. Di Ambarawa diisolasi dari hewan roden L. bataviae; L. icterohaemorrhagie; L. javanica; L. pyrogenes; dan L. semarang. Abdullah 1961 dapat mengisolasi L. autwnnalis; L. canicola; L. sarmini; L.schu! ieri; L. benyamin; L. asam; L. javanica; L. grippotyphosa; dan L.bovis, dari Rattus ratuss regni sody yang ditangkap di Bogor dan sekitarnya. ${ }^{16}$

Upaya pencegahan leptospirosis yang dapat dilakukan adalah melakukan imunisasi, hindari berenang, mandi, menelan atau menundukkan kepala ke air tawar yang berpotensi terkontaminasi 
seperti sungai, terutama setelah musim hujan atau banjir, menutup luka dan lecet pada perban kedap air, hindari kontak dengan air banjir dan tidak makan makanan yang terkontaminasi dengan air banjir, gunakan peralatan perlindungan pribadi yang sesuai seperti sepatu karet, baju tahan air/pakaian dan sarung tangan dan tidak makan makanan yang mungkin terpapar tikus dan mungkin terkontaminasi urin tikus. ${ }^{17}$

\section{KESIMPULAN \& SARAN}

Berdasarkan hasil penelitian yang diperoleh disimpulkan bahwa keberadaan bakteri Leptospira pada serum darah individu suspek dengan menggunakan Metode MAT didapatkan sebanyak 11 sampel serum darah positif. Kepada petugas kesehatan perlunya mengadakan dan meningkatkan kegiatan penyuluhan khusus tentang leptospirosis dan penegakan diagnosis pada masyarakat atau pekerja yang mengalami gejala atau suspek leptospirosis.

\section{REFERENSI}

1. WHO. Zoonoses: Leptospirosis. World Health Organization; 2010.

2. WHO. Zoonoses Leptospirosis: Burden Epidemiology Reference Group (LERG). World Health Organization; 2003.

3. Pratiwi, N. Analisis Temporal dan Spasial Unsur Iklim, Kepadata Penduduk, Daerah Rawan Banjir, dan Kasus Leptospirosis di DKI Jakarta Tahun 2007-2011. [Skripsi]. Depok: Universitas Indonesia; 2012.

4. ECDC. Annual Epidemiological Report Leptospirosis. European Centre for Disease Prevention and Control; 2015.

5. WHO. Leptospirosis in the Americas Surveillance and Drivers. World Health Organization; 2016.

6. Yunianto, B., T Ramadhani, T.R., Ikawati, B., Wijayanti, T \& Jarohman, J. Studi Reservoir dan Distribusi Kasus Leptospirosis di Kabupaten Gresik Tahun 2010. Jurnal Ekologi Kesehatan. 2012;11(1);40-51.

7. Depkes RI. Buku Pedoman: Penyelidikan dan Penanggulangan Kejadian Luar Biasa Penyakit Menular dan Keracunan Pangan. Jakarta: Direktorat Jendral Pengendalian Penyakit dan Penyehatan Lingkungan Kementerian Kesehatan Republik Indonesia; 2011.

8. Kemenkes RI. Data dan Informasi Profil Kesehatan Indonesia. Jakarta: Kementerian Kesehatan Republik Indonesia; 2018.

9. Rejeki, D.S.S. Faktor Risiko Lingkungan yang Berpengaruh terhadap Kejadian Leptospirosis Berat (Studi Kasus di Rumah Sakit Dr. Kariadi Semarang). [Tesis]. Jawa Tengah: Program Pascasarjana Epidemiologi Universitas Diponegoro; 2005. 
10. Pertiwi, S.M.B., Setiani, O \& Nurjazuli, N. Faktor Lingkungan yang Berkaitan dengan Kejadian Leptospirosis di Kabupaten Pati Jawa Tengah. Jurnal Kesehatan Lingkungan Indonesia. 2015;13(2):51-57.

11. Cahyati, W.H \& Lestari, F. Hubungan Kebersihan Pribadi dan Riwayat Luka dengan Kejadian Leptospirosis. KEMAS: Jurnal Kesehatan Masyarakat. 2009;5(1):70-79.

12. Haake, D, A \& Levett, P, N. Leptospirosis in Human. Australia: Spinger; 2015.

13. WHO. Leptospirosis. Geneva: World health Organization; 2015.

14. Kemenkes RI. Petunjuk Teknis Upaya Pengendalian Penyakit dan Penyehatan Lingkungan dalam Penanggulangan Bencana. Jakarta: Direktorat Jendral Pengendalian Penyakit dan Penyehatan Lingkungan Kementerian Kesehatan Republik Indonesia; 2013.

15. Dewi, H.C \& Yudhastuti, R. Faktor Risiko Kejadian Leptospirosis di Wilayah Kabupaten Gresik (Tahun 2017-2018). Jurnal Keperawatan Muhammadiyah. 2019;4(1):48-57.

16. Depkes RI. Kewaspadaan terhadap Penyakit Leptospirosis. Jakarta: Depkes RI Ditjen P2M dan PLP; 2003.

17. CDC. Leptospirosis: Fact Sheet for Clinicians. Centers for Disease Control and Prevention; 2018.

18. Syamsuar, M., Daud, A., Maria, I.L., Hatta, M \& Widyastuti, D. Identification of Serovar Leptospirosis in Flood-Prone Areas Wajo District. Indian Journal of Public Research and Development. 2018;9(9):325.

19. Lane, A.B \& Dore, M.M. Leptospirosis: A Clinical Review of Evidence Based Diagnosis, Treatment And Prevention. World Journal of Clinical Infectious Diseases. 2016;6(4):61-66.

20. Permata, A. \& Widayani, P. Citra Worldview-2 untuk Analisis Hubungan Genangan dan Habitat Tikus terhadap Kasus Leptospirosis di Kabupaten Bantul. Jurnal Bumi Indonesia. 2019;8(3). 